\title{
The Anthropologist's Video Camera as Stage
}

Forced Displacement and Production of Audio-visual Witnessing in Northern Sudan

\author{
Valerie Hänsch
}

\begin{abstract}
In this article, I explore how Sudanese communities have attempted to visually document, witness and communicate a silenced history of forced displacement. Thousands of peasants in rural Northern Sudan were flooded out of their homes along the Nile during the 2003-2009 Merowe Dam construction project. My aim is to examine both the complex local interactions with and appropriations of the anthropologist's video camera, which, in the relational process of witnessing, turned into a stage to provide audio-visual evidence against hegemonic discourses of Sudan's successful hydroelectric future. I show how my video camera's affordances of capturing and mediating 'truth' evoked specific performative genres of representation in moments of crisis and illustrate how these usages differ from everyday interactions with a video camera. These performative genres of 'crisis witnessing', I contend, resonate with globally distributed media realities and thereby reproduce certain practices of communication that are stereotyped in the mass media.
\end{abstract}

Keywords: audio-visual research, crisis, evidence, genre, media witnessing, Sudan, technology, truth

\section{Introduction}

'You have to film everything over there!' a man urged me while I was approaching a group of men on the banks of the Nile with my video camera. He pointed to a nearby village, to collapsed houses, submerged date trees and villagers who were trying to rescue their belongings from the rising river Nile. Meanwhile, another man detached himself from the group and approached my video camera. As his figure filled the frame, he began to make an appeal to the international community for support. 
I shot this scene in summer 2008 during my research among peasants in Northern Sudan threatened with displacement by the newly constructed Merowe Dam project located some fifty kilometres downstream. The men in front of the camera, some of whom I had met on different occasions, were representatives of the Manasir ethnic group who inhabited the remote area of the Fourth Nile Cataract at the margins of the Sudanese state. In 2003, the construction of the two billion US dollar mega-project had started with support from Germany, China and the Gulf countries; it was proclaimed a symbol of successful Islamic statecraft and development that would electrify the Sudanese nation. However, the question of dam-induced resettlement and displacement led to conflicting visions and tensions between the dam authorities and the local peasant communities. Before agreements on compensation modalities had been reached and before resettlement had taken place, the damming of the Nile started without warning in the summer of 2008.

Struggling with government-imposed media censorship and a weak local media infrastructure, people urged me to use my video camera to capture the forced eviction that was happening far below the threshold of official media coverage. Through having access to my video camera, my interlocutors placed great hope in the power of images to render visible what was denied by the government and the international companies involved.

In this sense, audio-visual witnessing is an aesthetic practice of making things visible and audible. Here I draw on Jacques Rancière's (2004) concept of 'the distribution of the sensible' that links politics and aesthetics. Aesthetics, in his view, is 'the system of a priori forms determining what presents itself to sense experience' (Rancière 2004: 13). Sensual perceptions, experiences, ways of meaning-making and being affected are determined by what he calls 'the distribution of the sensible, that is, the partition into what can be seen and said, who is visible or invisible, and what is permissible to say or to show within a society. According to Rancière (2010:37), politics then is 'an intervention in the visible and the sayable'. In my case study, it is the struggle of the displaced, the marginalized and the disenfranchised for recognition, support, justice and self-determination. Consequently, I examine aesthetic practices of audio-visual witnessing as a way to intervene in the sensible and thus reconfigure the order of things that appear to be self-evident.

As a visual anthropologist, I have filmed frequently during my various ethnographic research projects in the Sudan. What struck me most this time, in 2008, when the unexpected but feared flooding started, however, was that my interlocutors interacted with my video camera in a completely different way than during any other previous shooting in Sudan. In what follows, I try to make sense of, analyse and interpret my puzzling over the ways in which my video camera was used in order to produce audio-visual witnessing. I shall argue that my interlocutors deployed the video camera as a technological device inscribed with the expectation of capturing and representing the 'truth'. Yet the camera's perceived affordances of truth-telling and its entanglement with genres of 'crisis witnessing' do not exist independently, but need to be situated relationally between the camera, the 
anthropologist, the research participants and an imagined audience. One way of recognizing the relationship between the camera and the various actors is by paying attention to the 'affordances' (Gibson 1986) of the video camera that are implicated in modes of witnessing. As will become clear, these relationships constitute the production of audio-visual witnessing.

By exploring ethnographically how audio-visual witnessing is constituted and performed, I contribute to the growing anthropological work on witnessing (Reed-Danahay 2016) and the emerging studies on 'media witnessing' in the field of communication and media studies (Chouliaraki 2012; Frosh and Pinchevski 2009; Peters 2001). While the latter body of research mainly employs discursive analysis and concentrates largely on the semiotics of images in an increasingly mediatized world, anthropologists working on witnessing in the realm of human rights media have investigated how activists, NGOs, journalists and television stations produce media on human suffering and circulate it across global communication infrastructures (Allen 2009; McLagan 2006). Both approaches emphasize the affective dynamics of these media, which aim to testify and to make people's claims public in order to attract attention and elicit responses in the audience. The various media practices and representations of violence, suffering and human rights violation have contributed to the formation of different media genres of testimony (McLagan 2006; Schankweiler et al. 2019). However, less attention has been paid to the question of how these emerging genres shape audio-visual witnessing 'on the ground' among non-professional actors and involved anthropologists.

By attending to the interactions with my video camera and its evocative potential in moments of crisis, I will explore performative genres of audio-visual witnessing that resonate with globally circulated representations of human suffering. Anthropologists have frequently criticized media representation of helpless victims and its attendant emotional economy of sensation. Research in the fields of humanitarianism, violence and suffering has been questioned for its normative orientation and political entanglement in postcolonial contexts; anthropologists have discussed whether anthropological modes of witnessing should lead either to commitment and active engagements or to more 'neutral', independent and uncommitted ways of engagement (Angel-Ajani 2004; Marcus 2005; Scheper-Hughes 1995; Ticktin 2014). I will address these challenges by showing how witnessing is constituted and by critically reflecting on the tensions which the witnessing anthropologist experiences. I also consider the consequences for knowledge production which are implicated in the process of audio-visual witnessing.

First, I will situate audio-visual witnessing and discuss the evocative potential of the video camera. Before I elaborate on the genres of 'crisis witnessing' that I have identified, I will describe local media practices that shape communicative and performative forms of witnessing. My discussion is grounded in my experience of living with Manasir peasant families in several different villages. I started my ethnographic research at the Fourth Nile Cataract in 2006 prior to the displacement of the Manasir peasants, followed by one year of research in 2008-2009. In the following discussion, I focus in particular on the period when the inundation of 
the dam's reservoir commenced. This lasted for about ten months, from July 2008 until April 2009. Since then, I have continued to follow the events during research visits to the area in 2010,2015 and 2018.

\section{Situating audio-visual witnessing: the evocative camera}

In my various research projects, I have used the video camera both as a research instrument and for the collaborative production of ethnographic films (Hänsch 2004, 2009). I regard my work, especially filming, as a situated practice grounded in cooperation between the filmmaker (anthropologist) and the research partners. In my understanding, this approach enables intersubjective knowing and contributes to making anthropology relevant to the public. In contrast to texts, film is a highly sensory medium; it offers the immediacy of sensual experiences that evoke strong emotions and imaginations in the audience that go beyond the images and thus open up knowledge processes of complex connections and human experiences (MacDougall 2006: 42). Film, as a documentary form, produces certain realities rather than depicting any apparently fixed reality. However, the mimetic and indexical quality of film often produces a sense of realism for the audience, one which obscures the fact that recording rests on the interaction between the various actors as well as on location and positioning. Vision, whether the 'I' of the eyewitness or the camera eye, and hence the production of knowledge and truth, is always 'partial' and 'situated' rather than being a view from 'nowhere' (Haraway 1998: 197-198).

When I was first introduced to the area of the Fourth Nile Cataract in 2006, a colleague who had conducted extensive research among Manasir peasants asked me to make, together with villagers and leaders, a short documentary on the threat of future displacement posed by the dam construction project (Hänsch 2006). At that time not much was known internationally about the Merowe Dam and the film was intended to raise awareness about the mega-project and the injustices this generated. When I subsequently began my $\mathrm{PhD}$ research in the area, I took my video camera with me, intending to use it as a research instrument and possibly to produce another documentary.

When the flooding started in summer 2008, my interlocutors attributed the role of witness to me and the camera eye. While I was initially and primarily seen as a $\mathrm{PhD}$ student who had returned from Germany to stay for some time conducting research, I was also asked to audio-visually witness the critical events. In this process, I was struck by the fact that my video camera evoked specific performative and communicative forms of witnessing among my research partners. In order to understand this observation and make it analytically tangible, I first consider the affordances of a camera, that is, the potential it offers to articulate experiences and to capture 'reality'. James Gibson demonstrated in his outline of 'the theory of affordances' that 'affordances of the environment are what it offers ..., what it provides or furnishes' (1986: 127). Affordances of the environment offer possibilities for action. A bench, for instance, invites you to sit down. Yet the bench does not afford the same for a small child as for an adult if the height of the bench does not 
afford a child to sit on it. This means that affordances 'are not just abstract physical properties' but need to be seen as 'relative to the animal' (Gibson 1986: 127). The human species is included in Gibson's term 'animal'.

The properties of a video camera therefore need to be viewed as being relational to the actors (protagonists, filmmaker, audience) associated with it. For example, what the camera affords or what it constrains relates to the gender, age and social position of a person in a given society. In my research context in Sudan, public life and politics are highly gendered. Political discussions in public spaces are mostly male-dominated. Men would approach a camera quite differently than women, who, according to social norms and cultural values, are expected to act in a modest way. This means that affordances are not to be reduced to the function of an object. Graeme Were argues that 'affordances refer to the perceived and actual properties of objects' (2013: 585). The filming camera, for example, could be perceived as a surveillance camera, and actors might hide from it rather than interacting with it. Thus, the way that people act towards a camera depends also on the quality of the relationship between filmmaker (anthropologist) and protagonists.

Focusing on affordances helps to shed light on the agentive role of audio-visual technologies and situates the agency between the filming anthropologist, the camera and the research partners. This perspective avoids technological determinism. Instead, it allows for deeper examination of how the video camera is used, acted upon and perceived within a specific context and situation.

The visual anthropologist Jean Rouch recognized the agentive potential of the film camera to communicate experiences early on. For Rouch, the camera promotes the truth, and more precisely, the filmic truth; this is his synthesis of 'cinéma verité. While filming, according to Rouch, all those involved (filmmaker and protagonists) enter into a state of enchantment which he describes as 'ciné transe' (Rouch 1995: 90; 2003: 98). The 'enchantment' consists of the creative joy that arises when people immerse themselves in a situation with the camera and jointly produce reality - namely, the filmic truth. With his filmic approach, Rouch criticized positivist orientations and methods that considered the camera as a passive and objective instrument for depicting 'reality'. Even if research partners get used to the filming anthropologist in their everyday life, people improvise in front of the camera, interact with it and usually enjoy creating something together. They appropriate the video camera, use it for their own concerns and perform in front of it (cf. Turner 1991).

As my discussion indicates, the filming camera is undoubtedly evocative: it offers possibilities to act, and for utterances, self-representations and performances, but this happens, as I would like to show, in different ways. Interactions with the camera and forms of representation are not only related, as indicated above, to social positions, gender, the individual character of the protagonists, cultural norms and power relations, but also to media practices. In an increasingly mediatized world, the perceived properties of the video camera are grounded in everyday media practices of people, for example watching television or sharing pictures electronically (Hänsch 2017a). These ways of using and perceiving images contribute to 
the imagination of the world (cf. Belting 2011). In turn, these imaginations shape the properties that are attributed to a film camera. However, as I want to highlight here, affordances are not only relative to actors and to media practices and their ecologies (e.g. available media infrastructures), but are shaped above all by the situation in which actors find themselves.

Those people who are not acting in everyday situations, but instead experiencing fundamental existential threats, demand sympathy and attention; they want to convey their suffering, they appeal to others, they want to affect imagined audiences and thereby elicit responses. I call the forms of witnessing, which my camera afforded, genres of 'crisis witnessing'. Before elaborating on two genres that I have identified, I situate the Merowe Dam project and local media practices.

\section{The Merowe Dam project, media practices and the politics of in/visibility}

The recently overthrown Sudanese government previously celebrated the construction of the Merowe Dam (2003-2009) at the downstream end of the Fourth Nile Cataract in Northern Sudan as a milestone for Sudan's development and progress. With its capacity to double Sudan's energy production, the Sudanese Dams Implementation Unit (DIU) and the international companies involved presented the Merowe Dam as a blessing for Sudanese citizens.

For the benefit of the nation, more than seventy thousand riverine people had to make way for the reservoir. The Manasir (numbering approximately fifty thousand people) represent the majority (67 per cent) of the three ethnic groups forced to vacate their homelands (Hänsch 2012). In return, the then government promised them a better life in modern resettlement areas that included large-scale agricultural projects. According to government plans, the Manasir peasants were to be transferred to two large resettlement areas situated far away from the Nile in the desert areas of the central Nile valley. Glossy pictures of new concrete houses and large agricultural fields, aired on TV channels and published in development reports, presented a 'move to a better life' (DIU 2010: 50). These pictures and audio-visual reports of the governmental propaganda campaign painted a largely ameliorated life and a bright future for 'poor' peasants.

However, during a highly dynamic political process of negotiating resettlement and compensation modalities, the government side-lined the peasants, their voices and wishes. Confronted with increasing state coercion and exclusion from decisionmaking under the authoritarian regime, the majority of the Manasir developed a strong resistance against the government's resettlement vision of transferring people to faraway places. Instead, they struggled for a self-determined, alternative vision, lobbying to remain in their homeland and move to new settlement sites to be constructed directly around the future reservoir. This 'counter plan' came to be known as 'the local option' among the Manasir people. Only after demonstrations, threats of violence and the imprisonment of Manasir leaders was an agreement between the Manasir and the central government finally reached in 2006 and 2007. In this 
agreement, steps towards the construction of new settlement sites around the future lake, representing the 'local option', were guaranteed by the government. The highly politicized and emotionally charged question over staying or leaving led to severe social disruptions among the Manasir. Those who left for the governmental resettlement areas were considered as 'traitors' to the community. Here, I focus mainly on the proponents of the 'local option' who tried to realize the long-nurtured vision of staying around the emerging lake. More than two-thirds of Manasir families (about ten thousand families) attempted to stay in their homeland along the Fourth Nile Cataract, whereas only one-third (about two thousand five hundred families) resettled both before and during the flooding in 2007-2009 to the non-'local option' government sites (Hänsch 2012).

During the construction of the dam, the political representation of the Manasir, which consisted of local leaders and Manasir migrants living in the cities, had repeatedly drawn attention to the threat of forced displacement. Representatives wrote articles in national and international newspapers, and approached international NGOs. As the construction of the dam project progressed and the resettlement issues remained unresolved, tensions and state coercion increased. Confronted with media censorship under the repressive regime, online communication in discussion forums such as Sudanese Online or in the online journal Sudan Tribune became virtually the only outlet for reporting on marginalization, threats of violence and grievances. By reporting online, Manasir representatives based in the cities and abroad tried to intervene in the dominant state discourse which propagated supposedly successful resettlement processes and presented the Merowe Dam as a dazzling modernization project. However, in general, the problems of the Manasir and of the entire project met with little response both nationally and internationally. The government increasingly sealed off the area around the Fourth Nile Cataract by, among other things, setting up military camps in the vicinity of Manasir villages; NGOs and media representatives were denied access.

In July 2008, when the impoundment of the dam's reservoir started, the Sudanese government, the DIU and the German company Lahmeyer, which supervised the dam's construction, denied the fact that thousands of families were flooded out of their homes. Instead, images of resettled Manasir peasants were broadcast at prime time, celebrating the beginning of a better future and proving the relocation processes to the state-run resettlement areas to be successful.

Communication and reporting on the events of the Fourth Nile Cataract proved difficult for the inhabitants due to repression and inadequate media infrastructure. Though most villages in the remote region had been gradually integrated into the national mobile communication network in the last two decades, the connection was weak and often disrupted. Access to the internet was limited to a few villages, but the signal was too low to send or receive large amounts of data such as videos and pictures. Back then, the 'urban' wave of smartphone mobile use for digital communication had not yet reached the region. In the general absence of smartphones and the lack of video cameras at the beginning of the flooding, my interlocutors used the availability of my video camera to witness and convey a silenced reality. 
In doing so, they adopted specific performative forms of communication that were informed by representations of other crises and conflicts as portrayed in the mass media. The villagers' mass media consumption practices concentrated on listening to radio and above all watching TV. The number of TV devices had gradually increased during the recent decades among affluent households who pursued an urban lifestyle; these families mostly used their own TVs. Apart from that, in many villages individual families owned TV sets. In the evening, women, men and children from the village community gathered in front of the TV to watch Egyptian soap operas and news programmes broadcast on the Sudanese TV channel Sudani. Reports from the Dubai-based television station Al-Arabiya and especially news reports from the TV station Al-Jazeera were also popular among the villagers.

These practices of mass media consumption, I argue, served as a reference for ways of conveying their experiences and concerns. The villagers reproduced certain performative and communicative forms of representation through 'mimetic appropriation' (Ivanov 2017: 369). This mimetic process is not a passive, direct imitation of mass media discourse. Instead, it is an active process of appropriation, a remixing and reworking of media discourses (cf. Spitulnik 1997). In the following, I will present and analyse two of the most dominant genres of crisis witnessing that I encountered.

\section{Genres of crisis witnessing}

During the annual Nile flood, in July 2008, the dammed river Nile reached the first villages located closest to the riverbanks. At that time the villagers were still awaiting the construction of settlement projects in their vicinity (the 'local option'), which the central government had agreed to build. No official information about the dam was forthcoming and no efforts were made to warn the peasants. The situation was very tense and full of fear since reliable information as to how far the river would rise was unavailable. The village of my research partner Fatna was inundated within a mere seven days. Hurriedly, and with great difficulty, she and her family tried to rescue their belongings, dragging them to higher ground in the adjacent desert, where the men started to build improvised shelters from wood and palm leaves. The flooding of villages and the loss of agricultural land posed existential threats to the families. Their houses and crops alike had been destroyed by the rising waters, as were some livestock and other possessions. Refugee camps, built by the displaced peasants, formed along the fringes of the emerging reservoir. Elsewhere I have described the experience of a crisis, that is, when routines and habitual knowledge lose their validity to the extent that the taken for granted and the existential experience of a familiar everyday world is fundamentally shaken. This renders the future radically uncertain (Hänsch 2020). Indeed, the term 'crisis' appears as omnipresent in today's discussions of the world and has been critically engaged by several scholars (Roitman 2014). I do not take 'crisis' as an a priori, but refer instead to a phenomenological notion of 'crisis' (Schütz 2004) as a crisis of the life-world, a concept which encompasses the experience of my interlocutors. 
During the time when the flooding started, close research partners, Manasir representatives as well as peasants whom I met on my way through the submerging villages asked me at different places to record their verbal statements, the destruction and the flight to higher ground in the adjacent deserts. Some of them I knew from previous meetings, others I got to know only then when they asked me spontaneously to record their verbal statements. They had either seen me filming or heard that I carried a video camera.

The first genre of crisis witnessing that I have identified, I call 'political appeal and accusation'. In their narratives, given in the form of short statements, slogans or poems, the men explicitly addressed the international community. The very first time I met Ahmed, a peasant whose village, agricultural land and date trees had already perished, he appealed for help:

We call on the international aid organizations to distribute relief supplies to the citizens and children as quickly as possible! We are done! We have got nothing left! The river waters reached us, and we are staying on an island. The government did not give us anything!

For the recording of his statement, Ahmed positioned himself on rocks, against a background of half-flooded date trees. As he spoke, he vehemently supported his appeal with gestures and desperate facial expressions.

In another location, the Manasir representative mentioned at the beginning of this article approached my video camera and called on the International Criminal Court to investigate the submergence of the Manasir as quickly as possible. In his statement, he accused the government of committing a 'crime against humanity' and equated the flooding of inhabited villages with the war crimes committed by the government in Darfur. Shortly before, in 2008, the Chief Prosecutor of the International Criminal Court in The Hague had filed an arrest warrant against the former president Omar al-Bashir. The Manasir representative stated in his appeal: 'What is happening in Darfur now is continuing here ... and nobody believes it!'

As the quotations indicate, my recordings were supposed to render visible a crime committed by the Sudanese government. The government as well as the international companies involved were held accountable for the flooding. My interlocutors perceived the video camera as a technological device to which they attributed the ability to witness 'reality' in the same way as our eyes can see it. In this realist understanding of recording and documenting - which is, for example, also embraced by media activists of human rights organizations - the camera and the images it produces can capture and present 'reality' in a direct and unmediated way (McLagan 2003). Taking this perspective, my camera should 'film everything' in order to render 'true' a silenced reality by way of making it visible. To reveal the 'reality' to others implies making them 'believe', since 'seeing is believing' (Razsa 2014: 515). In the eyes of my interlocutors, the camera presented itself as a powerful technology to tell the truth, to provide evidence of a crime and to call for accountability and support. Thus, audio-visual witnessing here is an epistemic 
practice capable of producing radically different knowledge and able to intervene in powerful discourses 'from below'.

In the first days and weeks of the flooding, the atmosphere was very heated; sentiments of rage und humiliation prevailed among the evicted peasants. Men and women began chanting slogans in front of my camera, such as: 'To justice in The Hague!' At the same time, the people repeatedly declared that they would never leave the region, that they were committed to staying and defending their homeland to the end. They directly addressed the Sudanese government and demanded the construction of the promised local settlements and monetary compensation for lost properties. 'The local option and our rights in cash!' men, women and children chanted into my camera. ${ }^{1}$

Another dominant form of crisis witnessing that I encountered is what I call 'generalized complaint and victimhood'. Through the 'mimetic appropriation' of this genre, my interlocutors tried to convey their existential experiences. In many conversations, but also by spontaneously approaching my video camera, the evicted peasants expressed their indignation, fear and despair. Asha, a woman from the neighbouring village, who was about to rescue her belongings from the family house, told me while I was filming: 'We are very worried, the situation is very difficult'. Halima, my neighbour, whom I knew well, started to complain when I asked her if she thought the river would continue to rise:

The government drowned us. Our animals have drowned, our houses are destroyed, our crops are under water, our mango trees and our date trees are flooded. We are done! We have nothing left! Now we are sitting under the sun, in dust and in the sand. We have rescued ourselves from death, we have saved ourselves from the flooding.

At that time, she had already been staying for a few days in an improvised shelter after the river had flooded her house. It was socially accepted that both Asha and Halima spoke up in front of the camera because of their seniority.

Women and men alike repeatedly and expressively complained about the loss of their livelihoods, the death of sheep and goats, the loss of date trees and agricultural fields. In these complaints, the people communicated their hardship and fear of an uncertain future. It was impossible to predict what future life would look like and if people would manage to stay and make a living on the fringes of the ever-growing reservoir. However, in front of the camera, my interlocutors described a complex reality in a strongly generalized and simplified way. In some cases, the livestock (sheep and goats) had indeed perished by drowning, but in most cases they were still alive but facing a shortage of fodder. Furthermore, some provisions and belongings were salvageable from the rising waters.

With their generalized complaints, my interlocutors presented themselves as victims. In fact, they reproduced and perpetuated the very same stereotypical representations of human suffering as the mass media did - the kind of reportage which has attracted criticism (cf. Chouliaraki 2012; Wright 2002). Through this way of representing the lived experience of a crisis, people hoped to draw attention to 
and convey the gravity of the situation, and thus bring about a response from the national and international community.

With my analysis of the two genres of crisis witnessing, I do not want to imply that the evicted people 'staged' something in front of my camera. It was hardly possible to distinguish between 'acting' and 'being'. My interlocutors definitely experienced fundamental uncertainty and perceived themselves as victims and often felt powerless. With the political appeals, the generalized complaint and the self-representation as victims, they tried to communicate their experiences and the urgency of the situation as convincingly as possible. By using corroborative facial expressions and gestures and positioning themselves close to destroyed houses and inundated date trees, the situation could be depicted as drastically and impressively as possible. To make their appeals more forceful, some peasants decided to stand in the floodwaters. Behind a man who was about to make his statement, the wall of a house collapsed in the waters and almost killed him. Men who observed the situation commented that the collapsing wall would do very well for the recording. These ways of articulating and expressing experiences aimed at generating attention, sympathy and affective response in an imagined national and global audience; and ultimately, the aim was to provide visual counter-evidence.

Mass media depictions of conflicts and crises elsewhere in the world served as frames of reference for the evicted peasants. Broadcast media that focus on human suffering and interest provide news content loaded with emotional appeal (Allan and Zelizer 2004). Through the internalization of news journalism covering conflicts and crises, my interlocutors acquired an implicit sense of the workings of media and they consequently appropriated the forms of crisis communication they saw distributed in the mass media. In doing this, they translated the reality on the ground into a form that would be 'legible' to an imagined global public. In this way, the documentary witnessing of the camera was transformed into crisis witnessing.

Most of my interlocutors, except for some of the Manasir representatives, were not used to speaking to media representatives, such as journalists. Likewise, most were not accustomed to talking to NGOs, as the area is not frequented by national and international NGOs; it was the internalized news coverage in broadcast mass media that offered them a key reference point for how to act.

\section{Audio-visual witnessing and the anthropologist}

In the first weeks of the flooding, I was unable to break through the stereotyped and generalized way of representation that people adopted in front of my camera. As soon as I turned off the camera, my interlocutors talked about the situation and their experiences in a very different and more nuanced way. It was as if they suddenly switched to another mode in front of the camera. Even close research partners, with whom I had worked many times before the forced eviction took place, tended to over-simplify the situation and portrayed themselves as victims. During my previous filming in 2006, people explained to me in detail their fear of displacement and the politics involved. In the situation of existential uncertainty 
and crisis, hardly anyone presented a complex picture of the situation or reported in a detailed manner. My interlocutors aimed at gaining national and international attention, in the hope of changing their situation for the better and furthering their political project of staying in their homeland. The images should shake the world and my camera served as the stage.

Indeed, I tried to film other kinds of situations and conversations, for example the unfolding of a new everyday life or the building of refugee camps. This filming was welcomed as a form of historical documentation. In addition to rendering the injustices and crimes visible, it was equally important for the displaced villagers to visually document the process of forced displacement and the radically life-changing events which they wanted to be preserved as a historical document for remembrance and for future generations (Hänsch 2017b). However, at least at the beginning of the flooding, this form of documentation was frequently interrupted by the different modes of crisis witnessing the camera afforded.

If one takes a look at the news coverage of comparable collective crises, one can observe similar performances and narratives of victimhood, accusations of government and appeals to the international community. In a TV news report about the 2010 floods in Pakistan, for instance, the affected people accused the government of failing to provide aid and appealed to the international community, stating that everything was flooded and that they had lost everything. In the background, one could see destroyed houses and people wading through the floods. ${ }^{2}$

I have already shown that the communicative and performative acts my camera afforded are related to common local media practices and the existential experiences of a crisis. However, to complement the picture we also need to take into consideration the person behind the camera. In the situation of the flooding, I was not only perceived as an anthropologist, but was, moreover, identified as someone who would be able to communicate people's concerns in the mass media. Close research partners, friends and people who knew me all had hopes that I would spread their testimonies internationally in the mass media. Other peasants who did not know me so well immediately connected my camera with news journalism; I was perceived as a journalist. In moments of crisis, actors strongly associate the camera of someone from 'outside' with globally distributed media realities. In the first weeks of the flooding, Manasir representatives were able to bring a TV team from the Sudanese branch of Al-Jazeera to the area. The cameras of this team evoked similar communicative and performative forms of witnessing as my camera had, for example the political appeal, accusations and generalized complaints. ${ }^{3}$ In contrast, the video camera of Manasir representatives, who soon started filming, mainly documented the flooding, the destroyed houses and refugee camps. ${ }^{4}$ It is the video camera of the unknown or the outsider that carries the meaning of a stage from which to convey and disseminate concerns via the global mass media.

Like my interlocutors, I was overwhelmed by the experience of the flooding and I too felt the need to audio-visually document this historical moment and to witness the injustices, even though at that time it was not clear where this might be leading. But I also felt the 'burden of witnessing' and the responsibilities and ex- 
pectations this entailed (Chua and Grinberg 2021, this issue). This 'burden' became particularly noticeable when some Manasir representatives urged me to 'smuggle' the recordings out of the area as quickly as possible and distribute them via various communication and media channels. This was troubling because I did not want to expose myself and the people who appear in the recordings to the potential risk of being threatened by the government. Moreover, my options were limited back then. I drove to the capital Khartoum and edited a short video, which was uploaded to YouTube. ${ }^{5}$ When I came back to the area, word had spread that I had 'put something out' to the media, although I felt that this video did not fulfil the people's expectation of getting their story global media coverage ${ }^{6}$ Later, I also realized that my own video reproduced stereotyped representations of crisis witnessing resembling those in the mass media. In the editing process, I had picked the most dramatic scenes and statements. In the video, you can see people standing in the waters up to their hips and hear them accusing the government. You can also see refugee camps where women stare at each other apathetically. The video resembles the observational and realist style of filming that appears as a view from 'nowhere' instead of a view from 'somewhere'.

As anthropologists, how can we deal with situations in which our interlocutors ask us to act as witness? How do we deal with our involvement in witnessing processes? People in situations of crisis and conflict demand attention, support and firm stances from all parties involved. As one of my interlocutors said when we spoke about the engagement and non-engagement of scholars and scientists:

We do not want people to come and fight with us, but we want their moral support; the support to draw international attention to the problems here, so that what is happening in this part of the world becomes known.

This is an invitation to take on responsibility by contributing to making concerns visible and hence knowable to audiences which the researcher is attached to. The appeal appreciates the position of the outsider who circulates the recordings to different audiences that also offer different potentials. However, the production of audio-visual witnessing and associated stereotyped performances challenge ethnographic filmmaking and knowledge production which generally aspires to be reflexive and multivocal. In a highly politicized context, achieving multi-perspectivity is sometimes not possible. At certain moments, for instance, social tensions made it impossible for me to talk to people who wanted to move to the governmental resettlement sites. Their voices are also not included in my short video. Those who demanded the 'local option' would have seen my collaboration as complicity. It remains a challenge to anthropologists to resolve the tension between the described genres of 'crisis witnessing', the responsibility attributed to the researcher's camera and the anthropologist's endeavour to highlight multiple perspectives. 


\section{Conclusion}

In this article, I have explored the production of audio-visual witnessing as an aesthetic and epistemic practice among peasants who, on the one hand, used my video camera as stage in order to render 'true' their forced eviction and to call for national and international attention. On the other hand, the camera shaped the engagements by serving as a technological device for documenting and remembering historical events.

The performative genres of crisis witnessing that my camera's affordances evoked resonate with representations of human suffering circulated in the global mass media. By appropriating these representations, my interlocutors translated their experiences and concerns into a form that is 'legible' to the global public. I have argued that actors who face crisis situations and weak communication infrastructures associate the anthropologist's video camera with globally distributed media realities. This production of audio-visual witnessing can lead unwittingly to the perpetuation of dominant narratives and the downsizing of victimhood to homogenous portrayals of seemingly helpless victims devoid of agency.

This observation is not only significant for the discussion of the technologies of witnessing and its associated truth-claims in the realm of contemporary social media, particularly in a world increasingly associated with crises. It is also relevant to recent anthropological endeavours which seek to go beyond 'traditional' methods of collaboration, participation and observation by foregrounding joint interventions with their interlocutors as modes of collaborative knowledge production (Estalella and Sánchez Criado 2018; Fryer-Moreira 2021, this issue). As I have shown, forms of witnessing that aim at intervening by way of making realities visible and therefore possible might also serve to reduce complexity and so reinforce the dominant discourses and stereotypical depictions that we seek to avoid and de-centre. This is particularly relevant to witnessing as being in the moment; the 'truth' produced by a camera is one that is possible at that moment with that anthropologist and those interlocutors.

This discussion indicates that it is necessary to analyse what witnessing constitutes and to critically reflect on one's own position and involvement in the process. Just as in the many critical debates about ethnographic authority, power structures, moralities and hierarchies associated with participation and observation, anthropologists need to constantly reflect on how we practise witnessing. I have shown that witnessing is performative, affective, relational and contingent on the situation we are involved in. Anthropologists increasingly work in places that are characterized by 'regimes of intervention' (Marcus 2005: 32), such as humanitarian organizations, armed movements or, as in my case, development agencies. Confronted with these regimes and the constant pressure to take a firm stand, George Marcus (2005) suggests that political detachment is sometimes necessary. He advocates a more 'neutral' and independent practice of witnessing as 'a form of activism', which does not take political sides but tries to remain as critical as possible (Marcus 2005: 45). Witnessing anthropologists do not have to become full-blown activists or 
politically involved. However, as I have shown, it is sometimes not possible, if at all, to remain detached or impartial. In consequence, some voices are always prevented and excluded. This is particularly true for highly politicized contexts. And just as aesthetics and politics are inherently intertwined (Rancière 2004), audio-visual witnessing is always political and therefore an intervention that necessarily takes sides (or is taken to a side). At the end of the day, we still need to make a choice, while remaining critically aware of what we are doing.

The processes of witnessing change over time and through unfolding histories. My regular research visits to the region aim at the collaborative production of a long-term documentary that encompasses different phases of the displacement process, including the time before the flooding commenced. In this documentary the role of the witnessing camera is reflected as well as the changing practices, landscapes, sentiments and politics. It entails multiple voices, and those voices that were initially excluded. An anthropology that is oriented towards multimodality offers possibilities not only to participate in, but also to reflect on witnessing processes.

\section{Acknowledgements}

I thank my interlocutors, known here by various pseudonyms, for their support and willingness to share their experiences with me. Earlier versions of this article were presented first at the panel Anthropologies of Witnessing: Imaginaries, Technologies, Practices' at the RAI Conference 'Art, Materiality and Representation' (2018) in London, and at the Anthropological Colloquium, Department of Social Sciences, University of Basel (2018) as well as at the Mellon Sawyer Seminar 'Energy Justice in Global Perspective' (2019) at the University of California, Santa Barbara. I thank all participants for their comments and the lively discussions. I also thank the reviewers of the article for their valuable comments. Particularly, I thank the guest editors of this issue, Liana Chua and Omri Grinberg, for their continuous support since our journey on the publication process began in 2018 after the inspiring panel in London. Their collaborative spirit and insightful comments helped me to improve the article.

Valerie Hänsch is a postdoctoral researcher at the Department of Social and Cultural Anthropology, LMU Munich, and a visiting professor at the University of Bayreuth, Germany. She holds a PhD from the Bayreuth International Graduate School of African Studies (BIGSAS). In her work, she explores technologies, large infrastructures, uncertainty, socio-environmental transformations and displacement in the Sudan. Her latest research investigates the links between activism, aesthetic practices and affects in the Sudanese revolutionary process. As a visual anthropologist, she has produced several ethnographic films. Her film Sifinja-The Iron Bride (2009) has been awarded several prizes.

Email: valerie.haensch@ethnologie.lmu.de.

ORCID: https://orcid.org/0000-0002-0401-0623. 


\section{Notes}

1. To be precise, another genre of crisis witnessing can be distinguished here, which on a national level was directed explicitly at the Sudanese government but also at the resettled Manasir.

2. See https://www.youtube.com/watch?v=9LhABtgN5as.

3. See https://www.youtube.com/watch?v=NBzyrYDVOe4.

4. See for example https://www.youtube.com/watch?v=6du_fz0fFI8.

5. See https://www.youtube.com/watch?v=aBB_5sjLgZk.

6. I also contacted German television stations and asked them to report on the events in the region, but they refused because they did not have permission to film in Sudan. On another level, the audio-visual witnessing was transformed into an expert witnessing. In 2010, Manasir representatives together with the Berlin-based NGO European Center for Constitutional and Human Rights (ECCHR) filed a criminal complaint against the managers of the German dam-building company in Frankfurt am Main. After getting in touch with the ECCHR lawyer in charge of the case, I wrote an eyewitness report which was handed over to the prosecutor who was investigating the case (Hänsch and Saage-Maaß 2018). The prosecutor also asked me to hand over part of my audio-visual footage. In this process, I also participated in a public discussion together with the ECCHR and Manasir representatives. In this discussion, in which politicians and citizens in Frankfurt am Main participated, I also screened some edited footage of the flooding. The criminal case, which was closed in 2016 without the prosecutor bringing the case to trial, led to several newspaper reports and requests from journalists for interviews as an 'expert witness'.

\section{References}

Allan, S. and B. Zelizer (eds). 2004. Reporting War: Journalism in Wartime. Oxford: Routledge.

Allen, L. A. 2009. 'Martyr Bodies in the Media: Human Rights, Aesthetics, and the Politics of Immediation in the Palestinian Intifada'. American Ethnologist 36 (1): 161-180.

Angel-Ajani, A. 2004. 'Expert Witness: Notes toward Revisiting the Politics of Listening. Anthropology and Humanism 29 (2): 133-44. https://doi.org/10.1525/ ahu.2004.29.2.133.

Belting, H. 2011. An Anthropology of Images: Picture, Medium, Body, trans. T. Dunlap. Princeton, NJ: Princeton University Press.

Chouliaraki, L. 2012. The Ironic Spectator: Solidarity in the Age of Post-humanitarianism. Cambridge: Polity Press.

Chua L. and O. Grinberg. 2021. 'Introduction'. Cambridge Journal of Anthropology (this volume).

Dams Implementation Unit (DIU). 2010. 'Merowe Dam'. Monthly Scientific Magazine 8: $1-127$.

Estalella, A. and T. Sánchez Criado (eds). 2018. Experimental Collaborations: Ethnography through Fieldwork Devices. New York: Berghahn Books.

Frosh, P. and A. Pinchevski (eds). 2009. Media Witnessing: Testimony in the Age of Mass Communication. Basingstoke: Palgrave Macmillan.

Fryer-Moreira, R. 2021. 'We Were There: Rethinking Truth with Midiativistas in Rio de Janeiro'. Cambridge Journal of Anthropology (this volume).

Gibson, J. 1986. The Ecological Approach to Visual Perception. Boston, MA: Houghton Mifflin.

Hänsch, V. (dir.). 2004. Ramadan Karim. Germany/Sudan. 
Hänsch, V. (dir.). 2006. Manasirland - Development Refugees. Germany/Sudan. Hänsch, V. (dir.). 2009. Sifinja - The Iron Bride. Germany/Sudan. www.sifinja.de.

Hänsch, V. 2012. 'Chronology of a Displacement: The Drowning of the Manâsîr People'. In C. Kleinitz and C. Näser (eds), 'Nihna nâs al-bahar - We Are the People of the River'. Ethnographic Research in the Fourth Nile Cataract Region, Sudan. Wiesbaden: Harrassowitz, 179-228.

Hänsch, V. 2017a. 'Die evokative Kamera: Film, audiovisuelle Forschungstechniken und die lokale Resonanz globaler Medienkommunikation in Krisenmomenten am Nil, Nordsudan'. In M. Verne, P. Ivanov and M. Treiber (eds), Körper Technik Wissen: Kreativität und Aneignungsprozesse in Afrika [Body technology knowledge: creativity and appropriation in Africa]. Berlin: LIT, 107-121.

Hänsch, V. 2017b. 'On Visual Evidence: Picturing Forced Displacement in Northern Sudan'. Tsantsa 22: 100-111.

Hänsch, V. 2020. 'On Patience: Perseverance and Imposed Waiting during Dam-Induced Displacement in Northern Sudan'. Critical African Studies 12 (1): 79-92. https:// doi.org/10.1080/21681392.2019.1697317.

Hänsch, V. and M. Saage-Maaß. 2018. 'Responsibilities Overseas and Accountability at Home: A New Kind of Legal Case in Germany against Dam-Caused Displacement in Sudan' In M. Cernea and J. Maldonado (eds), Challenging the Prevailing Paradigm of Displacement and Resettlement. London: Routledge, 225-251.

Haraway, D. 1998. 'The Persistence of Vision'. In N. Mirzoeff (ed.), The Visual Culture Reader. London: Routledge, 191-198.

Ivanov, P. 2017. 'The Aesthetic Constitution of Space: Mimetic Appropriation of Foreign "Styles" and the Creation of Transoceanic Connections on the Swahili Coast'. Comparative Studies of South Asia, Africa and the Middle East 37 (2): 368-390. https:// doi.org/10.1215/1089201x-4132965.

MacDougall, D. 2006. The Corporeal Image: Film, Ethnography, and the Senses. Princeton, NJ: Princeton University Press.

Marcus, G. 2005. 'The Anthropologist as Witness in Contemporary Regimes of Intervention'. Cultural Politics 1 (1): 31-50. https://doi.org/10.2752/174321905778054890.

McLagan, M. 2003. 'Principles, Publicity, and Politics: Notes on Human Rights Media'. American Anthropologist 105 (3): 605-612.

McLagan, M. 2006. 'Introduction: Making Human Rights Claims Public'. American Anthropologist 108 (1): 191-195.

Peters, J. D. 2001. 'Witnessing. Media, Culture \& Society 23: 707-723. https://doi.org/ $10.1177 / 016344301023006002$.

Rancière, J. 2004. The Politics of Aesthetics: The Distribution of the Sensible, trans. G. Rockhill. New York: Continuum.

Rancière, J. 2010. Dissensus: On Politics and Aesthetics, trans. G. Rockhill. New York: Continuum.

Razsa, M. J. 2014. 'Beyond "Riot Porn": Protest Video and the Production of Unruly Subjects'. Ethnos 79 (4): 496-524. https://doi.org/10.1080/00141844.2013.778309.

Reed-Danahay, D. 2016. 'Participating, Observing, Witnessing'. In S. Coleman et al. (eds), Routledge Companion to Cultural Anthropology. Oxford: Routledge, 57-71.

Roitman, J. 2014. Anti-crisis. Durham, NC: Duke University Press.

Rouch, J. 1995. 'The Camera and Man'. In P. Hockings (ed.), Principles of Visual Anthropology. Berlin: Mouton de Gruyer, 79-98. 
Rouch, J. 2003. Ciné-Ethnography, trans. S. Feld. Minneapolis: University of Minnesota Press.

Schankweiler, K., V. Straub and T. Wendl. 2019. 'Image Testimonies: Witnessing in Times of Social Media'. In K. Schankweiler, V. Straub and T. Wendl (eds), Image Testimonies: Witnessing in Times of Social Media. London: Routledge, 1-29.

Scheper-Hughes, N. 1995. 'The Primacy of the Ethical: Propositions for a Militant Anthropology'. Current Anthropology 36 (3): 409-420.

Schütz, A. 2004. Relevanz und Handeln 1: Zur Phänomenologie des Alltagswissens [Relevance and action 1: on the phenomenology of everyday knowledge]. Konstanz: UVK Verlagsgesellschaft mbH.

Spitulnik, D. 1997. 'The Social Circulation of Media Discourse and the Mediation of Communities. Journal of Linguistic Anthropology 6 (2): 161-187. https://doi.org/10.1525/ jlin.1996.6.2.161.

Ticktin, M. 2014. 'Transnational Humanitarianism'. Annual Review of Anthropology 43 (1): 273-289. https://doi.org/10.1146/annurev-anthro-102313-030403.

Turner, T. 1991. 'The Social Dynamics of Video Media in an Indigenous Society: The Cultural Meaning and the Personal Politics of Video-Making in Kayapo Communities'. Visual Anthropology Review 7 (2): 68-76. https://doi.org/10.1525/var.1991.7.2.68.

Were, G. 2013. 'On the Materials of Mats: Thinking through Design in a Melanesian Society'. Journal of the Royal Anthropological Institute (N.S.) 19: 581-599. https:// doi.org/10.1111/1467-9655.12051.

Wright, T. 2002. 'Moving Images: The Media Representation of Refugees'. Visual Studies 17: 53-66. https://doi.org/10.1080/1472586022000005053. 